\title{
Rill morphological change characteristics and influencing factors on different soil types in the Loess Plateau, China
}

\author{
zimiao he ${ }^{1}$, xinxiao $\mathrm{yu}^{1}$, Qiang $\mathrm{Cai}^{2}$, Jijun $\mathrm{He}^{3}$, shilong hao ${ }^{4}$, haiyan fang ${ }^{5}$, guodong jia ${ }^{1}$, \\ and Liying Sun ${ }^{6}$ \\ ${ }^{1}$ Beijing Forestry University \\ ${ }^{2}$ Chinese Academy of Science \\ ${ }^{3}$ Capital Normal University \\ ${ }^{4}$ Yellow River Institute of Hydraulic Research \\ ${ }^{5}$ Chinese Academy of Sciences, Beijing \\ ${ }^{6}$ Institute of Geographical Sciences and Natural Resources Research, CAS
}

January 23, 2021

\begin{abstract}
Soil properties play an important role in rill development and erosion. In this investigation, rill morphology developmental processes under sandy loam (SL), light loam (LL), medium loam (ML) and heavy loam (HL) soils on the Loess Plateau, China, were compared using laboratory experiments. Experimental analysis included two rainfall intensities $(90$ and $120 \mathrm{~mm} / \mathrm{h})$ and four slope treatments $\left(0^{\circ}, 15^{\circ}, 20^{\circ}\right.$ and $\left.25 \%\right)$. Results indicate that HL is the most prone to rill development, and SL, LL and ML are prone to rill development under heavy rain, with SL rill erosion being the most sensitive to heavy rain. The development of rills in SL are mainly characterized by an increase in rill width and merging nodes; rills in HL were mainly characterized by an increase in rill length, merging nodes and rill number. LL and ML rill development indices were between SL and HL. Differences in runoff collection caused by rill morphology differences further promoted differences in soil erosion. Rainfall intensity has a positive effect on rill shape parameters of all soils; slope has a positive and negative double effect on SL, LL and ML rill shape parameters, and only a positive effect on HL rill shape parameters. The sensitivity of rill parameters to rainfall intensity and slope angle depends on soil infiltration performance, surface soil stability and soil structure stability. Based on soil characteristic factors and rill morphological parameters, an empirical model of slope erosion in the loess region was established.
\end{abstract}

Rill morphological change characteristics and influencing factors on different soil types in the Loess Plateau, China

Zimiao $\mathrm{He}^{1}$, Xinxiao $\mathrm{Yu}^{1}$, Qiangguo $\mathrm{Cai}^{2,3}, \mathrm{Jijun}^{\mathrm{H}} \mathrm{He}^{4}$, ShiLong $\mathrm{Hao}^{5}$, HaiYan $\mathrm{Fang}^{2,3}$, Guodong $\mathrm{Jia}^{1}$, Liying $\operatorname{Sun}^{2,3 *}$,

${ }^{1}$ Key Laboratory of State Forestry Administration on Soil and Water Conservation, College of Soil and Water Conservation, Beijing Forestry University, Beijing 100083, China

${ }^{2}$ Key Laboratory of land water cycle and surface processes, Institute of Geographical Sciences and resources, Chinese Academy of Sciences, Beijing, 100101

${ }^{3}$ School of resources and environment, University of Chinese Academy of Sciences, Beijing, 100049

${ }^{4}$ Capital Normal University, State Key Laboratory of urban environmental processes and digital simulation, Beijing Key Laboratory of resources, environment and GIS, Beijing, 100048 
${ }^{5}$ Yellow River Institute of Hydraulic Research Key Laboratory of Soil and Water Loss Process and Control on the Loess Plateau of Ministry of Water Resources, 450003, Zhengzhou China

*Corresponding author at: Key Laboratory of land water cycle and surface processes, Institute of Geographical Sciences and resources, Chinese Academy of Sciences, Beijing, 100101. E-mail address:sunliying@igsnrr.ac.cn

\title{
Acknowledgments
}

This research was supported by the National Natural Science Foundation of China (Nos. 41771314,41977069), the Fundamental Research Funds for the Central Universities (2019ZY35) the Project of the Key Laboratory of Soil Erosion Process and Control in the Loess Plateau of the Ministry of Water Resources (No. 2016004). We thank Let Pub (www.letpub.com) for linguistic assistance during the preparation of this manuscript.

\begin{abstract}
:
Soil properties play an important role in rill development and erosion. In this investigation, rill morphology developmental processes under sandy loam (SL), light loam (LL), medium loam (ML) and heavy loam (HL) soils on the Loess Plateau, China, were compared using laboratory experiments. Experimental analysis included two rainfall intensities $\left(90\right.$ and $120 \mathrm{~mm} / \mathrm{h}$ ) and four slope treatments $\left(0^{\circ}, 15^{\circ}, 20^{\circ}\right.$ and $\left.25 \%\right)$. Results indicate that $\mathrm{HL}$ is the most prone to rill development, and SL, LL and ML are prone to rill development under heavy rain, with SL rill erosion being the most sensitive to heavy rain. The development of rills in SL are mainly characterized by an increase in rill width and merging nodes; rills in HL were mainly characterized by an increase in rill length, merging nodes and rill number. LL and ML rill development indices were between SL and HL. Differences in runoff collection caused by rill morphology differences further promoted differences in soil erosion. Rainfall intensity has a positive effect on rill shape parameters of all soils; slope has a positive and negative double effect on SL, LL and ML rill shape parameters, and only a positive effect on HL rill shape parameters. The sensitivity of rill parameters to rainfall intensity and slope angle depends on soil infiltration performance, surface soil stability and soil structure stability. Based on soil characteristic factors and rill morphological parameters, an empirical model of slope erosion in the loess region was established.
\end{abstract}

Keywords: soil types; rill morphological; rainfall intensity; soil loss; the Loess Plateau

\section{Introduction}

Rill erosion is an important process of slope hydraulic erosion, being the main component of slope hydraulic erosion prediction models (Foster et al., 1995; Shen et al., 2015; Assouline et al., 2017; Zhang et al., 2019). Rill erosion not only accelerates slope erosion and the transport of erosion products (Guo et al., 2020; Gordon et al., 2012, Vereecken et al., 2016), it also controls the development of watershed geomorphology and the evolution of morphological characteristics (Mancilla et al., 2005; Oz et al., 2017; Wu et al., 2018). In rill erosion processes, rill morphology is the result of interactions between hydrodynamic factors and soil properties (Schneider et al., 2013; Assouline et al., 2017; Wu et al., 2020). Although the presence of rills results in more water flowing into rills from inter-rills, thereby increasing rill flow erosivity and the sediment transport capacity of runoff (Robichaud et al., 2010; Wu et al., 2018), an increase in runoff erosivity and sediment transport capacity aggravates rill morphology evolution (Schneider et al., 2013; Zhang et al., 2019). Therefore, the evolution of rill morphology, hydrodynamic characteristics and soil erosion form a complex mutual feedback process. Quantitative description of rill morphology and the relationship between rill morphological evolution, runoff and sediment yield are important to fully understand rill erosion, promoting the development of soil erosion simulation.

Currently, investigations have been undertaken on rill cross-section shape (rill width, depth, width depth ratio, etc.) (Mancilla et al., 2016; Shen et al., 2016; Oz et al., 2017) and rill network characteristics (average 
rill azimuth, rill density, rill cutting degree and average rill bending complexity, rill number and discontinuous rill number, rill fractal dimension) (Gómez et al., 2003). The development process of rills has been quantified from three perspectives (Govers et al., 2007; Shen et al., 2015; Zhang et al., 2017; Wu et al., 2018), as well as using the degree of connectivity (the number of combined nodes and bifurcation ratio) (Schneider et al., 2013; Zhang et al., 2017). Although these methods provide indices for characterizing rill networks, the indicators ignore rill evolution during rainfall runoff and soil erosion processes. In order to improve erosion model accuracy, these rill characteristics have recently been incorporated into slope erosion models, resulting in an improvement in model results. For example, Wu et al. (2020) constructed a model to embed rill evolution module into hillside rainfall runoff erosion processes. However, their experimental materials were mainly concentrated in one or a few types of soil, and the effects of soil properties on rill erosion morphology and sediment yield were not systematically considered. Due to changes in soil properties and the complexity of soil erosion processes, each function can only be used for the soil erosion model under similar soil or experimental conditions.

The effects of soil properties on slope erosion and rill morphology are often ignored. Soil type and soil texture have significant effects on soil separability, particle size distribution of eroded sediment and morphological characteristics of erosion (Knapen et al., 2007). The difference of soil physical properties is the internal influencing factor of erosion processes and rill erosion (Dong et al., 2014; He et al., 2014; Wu et al., 2017). Soil properties determine the soil shear strength and stripping rate, directly affecting the occurrence of slope erosion. Bonilla et al. (2012) found that the correlation between silt content and soil separability was the largest, followed by sand content, while the correlation between clay content and soil erodibility was the weakest. Processes of soil separation and sediment transport are also closely related to the size of primary and aggregate soil particles (Rienzi et al., 2013). At the same time, soil properties affect the formation and stability of soil crusts, change surface soil permeability, and regulate runoff and runoff velocity, having an important impact on slope erosion and rill morphology (Vaezi et al., 2017; Mahalder et al., 2018; Sun et al., 2020). Soil properties are also closely related to soil structure stability. Under different rainfall intensities, different soil structure stabilities will have an important impact on gully wall stability (Xu et al., 2015; Guo et al., 2019).

As a key agricultural area in northwest China, the Loess Plateau has suffered from serious soil erosion for decades, and rill landforms formed by water erosion have serious impacted agricultural production (Wu et al., 2018; Sun et al., 2020). At the same time, soil in the Loess Plateau has a consistent particle size composition (0.05-0.005 mm silt, accounting for $58 \%-75 \%)$ and zonality of particle size distribution. Zonality shows that grain size of loess gradually becomes fine from the northwest to the southeast, coinciding with sandy soil, light soil, medium soil and heavy soil zones, respectively. Loess grain size differences in the north-south direction have a profound impact on landforms and soil erosion. Although many experiments have been undertaken to study the process and mechanism of water erosion in the Loess Plateau (Fang et al., 2015; Shen et al., 2016; He et al., 2017), it is still unclear how changes to soil properties in different regions affect rill morphology during surface erosion, and the accuracy of the regional erosion prediction model with multiple soil types needs to be further improved. Therefore, a series of simulated rainfall experiments were carried out in different soil zones to examine the following objectives: (1) to examine the effects of soil characteristics on rill morphology (2); to discuss differences in different types of soil slope erosion responses to rainfall intensity and slope angle; and (3) to establish a prediction model of slope erosion based on soil characteristic factors and rill shape factors. Findings from this investigation will improve our understanding of erosion mechanisms of multiple soil zones. 


\section{Materials and methods}

\subsection{Experiment materials}

The experiment was carried out in the artificial rainfall hall of the State Key Laboratory of soil erosion and dryland agriculture, Institute of soil and water conservation, Ministry of water resources, Chinese Academy of Sciences. A movable and adjustable steel soil trough $(5 \mathrm{~m}$ long $\times 1 \mathrm{~m}$ wide $\times 0.5 \mathrm{~m}$ high $)$ was used. Experimental rainfall mode consisted of a downspray rainfall system. To ensure that all raindrops reached a final speed, rainfall height was set at $18 \mathrm{~m}$ (He et al., 2017).

According to the zonal division of soil in the Loess Plateau (Li et al., 1985), a sandy loam (SL; Suide), a light loam (LL; Ansai), a medium loam (ML; Changwu) and a heavy loam (HL; Yangling) were sampled from different soil zones from the north to the south across the plateau (Fig. 1). All samples were collected from the soil surface of local cultivated land. For the four soil types, soil bulk density was $1.34 \mathrm{~g} / \mathrm{cm}^{3}$ (SL), $1.26 \mathrm{~g} / \mathrm{cm}^{3}$ (LL), $1.21 \mathrm{~g} / \mathrm{cm}^{3}$ (ML) and $1.13 \mathrm{~g} / \mathrm{cm}^{3}$ (HL). Organic matter content was determined using the potassium dichromate heating method (Nelson and Sommer, 1982), mechanical composition was determined using the laser particle size analysis method (Vaezi et al., 2017), and a wet sieving method (Castro et al., 2002) was used to determine water stable aggregate content. For each analysis three replicas were conducted. Soil properties are shown in Table 1.

\subsection{Experimental design and process}

Before analysis, soil samples were air dried, passed through a $10 \mathrm{~mm}$ sieve, and had weeds and stones removed. In order to keep permeability of test soil as close as possible to that on the natural slope, the bottom of the test steel tank was filled with a $10 \mathrm{~cm}$ thick layer of fine sand upon which a permeable fine gauze was laid. The remainder of the steel tank was then filled with test soil using a layered filling method. During filling the soil was compacted at the same time. Each filling layer was $5 \mathrm{~cm}$ thick, and the total filling thickness in the tank was $30 \mathrm{~cm}$. Bulk density of soil in the experimental tank was equivalent to that of the natural soil. In order to reduce the influence of the sidewall effect as much as possible, clapboards were compacted as much as possible when soil was loaded. After loading, the soil surface was leveled using a ruler and placed in the rainfall area for analysis. Four slope grades $\left(10^{\circ}, 15^{\circ}, 20^{\circ}\right.$ and $\left.25^{\circ}\right)$ were used in the experiment and each slope was tested under two rainfall intensities $(1.5$ and $2.0 \mathrm{~mm} / \mathrm{min})$. In order to ensure that final rainfall was equal, corresponding rainfall durations were set at $60 \mathrm{~min}$ and $45 \mathrm{~min}$, respectively.

During rainfall simulation, sediment and runoff samples were collected at the slope outlet, having a sampling interval of $1 \mathrm{~min}$. Sediment volume was determined using the drying method. Slope runoff velocity was determined using the color tracer method $\left(\mathrm{KMnO}_{4}\right.$ solution). Velocity measurement included slope velocity, rill velocity after rill formation and rill velocity between rills. Starting from the slope section at the bottom of the slope, flow velocity at 4, 3,2 and $1 \mathrm{~m}$ from the top of the slope was continuously measured. Before and after the experiment, DEM micro terrain surface data was collected using a 3D laser scanner (scanning 2), having an accuracy of $1 \mathrm{~mm}$. At the same time, a high-definition camera was used to record slope morphology changes during the rainfall process.

\subsection{Data analysis}

DEM data form the soil trough was denoised using cyclone software. DEM for the whole slope was obtained after invalid points were removed. At the same time, ArcGIS software was used to extract rill length, width, depth and density data; other characteristic parameters of rill erosion were also calculated. 


\section{Results and discussion}

\subsection{Soil erosion rate}

Under a rainfall intensity of $90 \mathrm{~mm} / \mathrm{h}$, the soil erosion variation range rate for the four soil types was 1.8-35.4 $\mathrm{g} \mathrm{min}^{-1} \mathrm{~m}^{-2}$ (SL), 27.1-135.4 $\mathrm{g} \mathrm{min}^{-1} \mathrm{~m}^{-2}$ (LL), 16.5-76.0 $\mathrm{g} \mathrm{min}^{-1} \mathrm{~m}^{-2}$ (ML) and 105.2-467.1 $\mathrm{g} \mathrm{min}^{-1} \mathrm{~m}^{-2}$ (HL), having the order of SL $<$ LL [?] ML $<$ HL (Fig. 2). When rainfall intensity was $120 \mathrm{~mm} / \mathrm{h}$, the rate of soil erosion for the four soil types increased by 11.9 times (SL), 1.6 times (LL), 2.3 times (ML) and 1.4 times (HL). Erosion rate at SL was the most sensitive to an increase in rainfall intensity, and the overall order of soil erosion rate was ML [?] LL $<$ SL $<$ HL. These results indicate that rainfall intensity plays a major role in soil erosion. Soil erosion rate with slope recorded an initial increase for SL and HL before decreasing as the angle of slope increased; maximum erosion rates were recorded at 15deg and 20deg, respectively. The soil erosion rates for LL and ML had no regularity with an increase in slope angle.

In order to further analyze causes for different types of soil erosion, differences in erosion rate before rills were formed were analyzed. Results indicate that, although no significant differences in SL, LL or ML were recorded, a significant difference between SL, LL, ML and HL was evident (Fig. 3). As shown in Fig. 2, significant differences among the four soils during the whole soil erosion process were also recorded. Comparison of these results indicate that differences of SL, LL and ML soil erosion were mainly caused by differences in rill erosion. These results also indicated that an increase of soil erosion rate caused by different types of soil rill erosion was not obvious when rainfall intensity was $90 \mathrm{~mm} / \mathrm{h}$. When rainfall intensity was $120 \mathrm{~mm} / \mathrm{h}$, SL rill erosion caused a sharp increase in the soil erosion rate; LL rill erosion caused a strong increase in the soil erosion rate; and ML rill erosion caused a slight increase in the soil erosion rate. An increase in the soil erosion rate caused by HL rill erosion was not obvious.

\subsection{Morphological development and occurrence of rills}

\subsubsection{Occurrence of rills}

Runoff characteristics and rill generation time (Table 2) indicate that, when rainfall intensity was $90 \mathrm{~mm} / \mathrm{h}$, rills were evident in all slopes under the HL soil type. For SL, LL and ML, rills were only recorded with slope angles of $15 \mathrm{deg}, 20 \mathrm{deg}$ and $25 \mathrm{deg}$, respectively. The occurrence time of rills gradually decreased with a decrease in particle size, a finding that is consistent with the variation law of runoff generation time (Table 2). Under a rainfall intensity of $120 \mathrm{~mm} / \mathrm{h}$, rills appeared in HL and SL at all four slopes; LL recorded an absence of rills at $15 \mathrm{deg}$ and $25 \mathrm{deg}$, and ML had no rills at $10 \mathrm{deg}$. Rill frequency results indicate that HL was the most prone to the formation of rills, and rills occurred more frequently at SL, LL and ML under heavy rain, with SL being the most sensitive to heavy rain. Under different rainfall intensities and slopes, a decrease in loess particle size resulted in a gradual decrease in runoff generation time, and average runoff rates before rill formation gradually increased (Table 1 and Table 2). However, the uniformity of soil particle size composition and the size of aggregates affects topsoil stability (Neyshabouri et al., 2011; Madenoglu et al., 2020). In general, the stability of topsoil decreases with a decrease in uniformity of soil particle size composition and an increase in aggregate size (Neyshabouri et al., 2011). Our results indicated that particle size composition of ML and HL was uniform (Table 1), and that particle size of aggregates was larger. Although these characteristics were conducive to runoff stripping and scouring, organic matter content in ML was higher than in the other soil types, thus enhancing surface soil stability. Before rill formation, HL recorded rates of runoff and soil erosion. A large volume of sediment was stripped and transported, resulting in the formation of an uneven slope, thereby creating conditions for concentrated flow. HL was also recorded to have the highest clay content of the soil types, thus being more readily stripped and scoured, thus being the main reason why this soil type was prone to rill formation.

As previously recorded (He et al. 2017), rills are mainly caused by heavy rainfall intensity; consistent with our results, rills typically increase with an increase in rainfall intensity (Berger et al., 2010). Rainfall intensity affects soil erosion through raindrop strike and runoff (Vaezi et al., 2018). Large rainfall intensity increases 
instantaneous runoff, and an increase in raindrop strike increases runoff disorder, which increases runoff erosivity, thus increasing the probability of rill generation. By comparing runoff rate and runoff velocity under different types of soil before rill formation indicated that rill formation is more sensitive to an increase in runoff rate caused by an increase in rainfall intensity. Under a rainfall intensity of $90 \mathrm{~mm} / \mathrm{h}$, SL runoff was low, and runoff was difficult to converge, therefore not being conducive to the generation of rills. Under a rainfall intensity of $120 \mathrm{~mm} / \mathrm{h}$, the increase in raindrop splash erosion and runoff promoted the removal and transportation of sediment, resulting in the formation of an uneven slope. As SL contained the largest sand content, a loose structure and the lowest content of organic matter, this soil type had poor structural stability. Once uneven points are present in a soil, it will quickly collapse, promoting the generation of rills. Heavy rainfall intensity also increased stripping and transportation of sediment under LL and SM soil types. However, due to LL and ML having higher clay and organic matter contents, soil structural stability of these soil types increased, resulting in a reduction of soil collapse. At the same time, because silt and sand contents were still large, erosion and scouring were not easily undertaken, thus rills did not readily form under LL and ML soils. Even when rills did form under these soil types, formation took a long time to occur.

Although SL, LL and ML rills did not record an obvious change with slope gradient, rills still mainly occurred on slopes with a greater gradient, indicating that slope gradient was an important factor affecting rill development (Mancilla et al., 2005). Slope affects rill generation by affecting rainfall, the runoff dynamic gradient and soil stability (Bagarello et al., 2010; Langhans et al., 2014; Jerzy et al., 2016). In general, the hydraulic gradient of runoff from a steep slope is large. This increases the velocity of slope flow and increases the shear force of slope runoff; at the same time, the instability of a steep soil slope increases, and the component force along the slope surface increases. Sediment is therefore removed by runoff, thus being conducive to the occurrence of rills (Komatsu et al, 2011; Ries et al., 2014; Zhang et al., 2016). However, under the influence of reduced the area of land experiencing rainfall, the impact of slope on runoff has a critical value. The sensitivity of different types of soil to a reduction of rainfall differs, and the occurrence time and probability of rills vary with slope angle.

\subsubsection{Morphological development of rills}

Different indicators are currently used to quantify the development process of rills from the aspects of rill cross-section morphology, rill network characteristics and connectivity. In this study, cumulative rill length $(\mathrm{CDL})$, average rill width (WA), average rill depth (Ha), rill density (DS), rill merging node $(\mathrm{J})$ and rill number $(\mathrm{N})$ were selected from these aspects to quantify rill morphology variation with rainfall. These variables were also used to clarify differences in rill development processes for the different types of soil, such as headward erosion, rill wall collapse and rill bottom undercutting.

Results for change process of CDL with rainfall (Fig. 4) indicated that SL, LL and ML had an approximate linear increase with an increase in rainfall; the increment of increase, however, was small. CDL of HL recorded an initial rapid increase as rainfall increased; after this the rate of increase declined. The increment for HL was large. At the end of the rainfall experiment, CDL range for SL, LL and ML was 1.5-4.8 m, and there was no obvious sequence relationship among these soils. CDL range for HL was 8.2-41.7 m. CDL for SL increased with an increase in rainfall intensity, and CDL changes for LL, ML and HL were almost not affected by rainfall intensity. CDL for SL initially increased before decreasing with an increase in slope, reaching a maximum when the angle of slope was $15 \mathrm{deg}$. CDL for LL and ML did not record a change with an increase in slope angle; CDL results for HL recorded an increase as the angle of slope increased.

Results for Wa change process with rainfall (Fig. 5) recorded an increase with an increase in rainfall duration. Results for SL and LL recorded an initial rapid increase before the rate of increase declined; ML recorded a rapid increase at $20 \mathrm{deg}$ and $25 \mathrm{deg}$ under a rainfall intensity of $120 \mathrm{~mm} / \mathrm{h}$, having an initial rapid increase and then increasing slowly under other conditions. At the end of the rainfall experiment, Wa for the different soil types was: HL $<$ ML [?] LL $<$ SL, in which Wa of SL ranged from $12.6-24.2 \mathrm{~cm}$, ML and LL ranged from $3.4-15.0 \mathrm{~cm}$, and HL ranged from $1.6-2.5 \mathrm{~cm}$. The influence of rainfall intensity on Wa of SL and HL was not obvious; Wa of LL and ML increased with an increase in rainfall intensity. Wa recorded a decrease 
for SL with an increase slope angle; LL and ML recorded an increase in Wa with an increase in slope angle; and HL recorded no change.

Ha recorded a general trend of increase with rainfall (Fig. 6). Ha results for SL, LL and HL all recorded a rapid initial increase before the rate of increase declined; Ha for ML recorded an initial rapid increase under a rainfall intensity of $120 \mathrm{~mm} / \mathrm{h}$. At the end of the rainfall experiment, no obvious sequence relationship was identified between Ha under all soil types in the range of 2.5-10.7 cm. The influence of rainfall intensity on Ha under SL, ML and HL is therefore not obvious. Ha under LL recorded an increase with rainfall intensity. Ha under SL recorded an initial decrease before increasing as the angle of slope increased, with the maximum value occurring when the angle of slope was $10 \mathrm{deg}$. Ha of LL and HL increased with an increase in slope angle. Under a rainfall intensity of $120 \mathrm{~mm} / \mathrm{h}, \mathrm{Ha}$ under ML decreased with an increase in slope angle.

The change process of DS with rainfall (Fig. 7) recorded an increase as rainfall duration and rainfall intensity increased for all soil types. However, under a rainfall intensity of $120 \mathrm{~mm} / \mathrm{h}$, the increasing trend of DS under different types of soil gradually declined. At the end of the rainfall experiment, DS for the different soil types was in the order of: ML $<\mathrm{SL}<\mathrm{LL}<\mathrm{HL}$. DS ranged from $0.2-2.2 \mathrm{~m} / \mathrm{m}^{2}$ for SL, LL and ML, and from $3.2-7.6 \mathrm{~m} / \mathrm{m}^{2}$ for HL. DS of SL initially increased before decreasing as the angle of slope increased, reaching a maximum at 20deg. DS under LL and HL increased as the angle of slope increased, and DS under ML was irregular.

Results for the change process of $\mathrm{J}$ with rainfall (Fig. 8) indicated that $\mathrm{J}$ under SL easily occurred under a rainfall intensity of $120 \mathrm{~mm} / \mathrm{h}$ and a slope angle ranging from $10 \mathrm{deg}$ to $20 \mathrm{deg}$. Results indicated that $\mathrm{J}$ did not easily form under LL and ML soil types; J also easily formed under HL. When rainfall intensity was $90 \mathrm{~mm} / \mathrm{h}, \mathrm{J}$ under HL rapidly increased with an increase in rainfall duration. When rainfall intensity was $120 \mathrm{~mm} / \mathrm{h}, \mathrm{J}$ recorded a rapid initial increase before increasing slowly with rainfall duration under SL and HL soil types. At the end of the rainfall experiment, the variation range of SL and HL was 2-6 and 5-24, respectively. Although $\mathrm{J}$ recorded an increase with an increase in slope intensity under SL and HL, it was not readily apparent at $25 \mathrm{deg}$ under SL.

Change processes of $\mathrm{N}$ under all soil types recorded an increase with rainfall duration (Fig. 9), being characterized by an initial rapid increase which then declined. HL recorded the most N, ranging from 9 to 40. There was no obvious order relationship among SL, LL and ML, with N ranging from 1 to 7 . Results for rainfall intensity recorded $\mathrm{N}$ to increase under all soil types. With an increase in slope angle, $\mathrm{N}$ under SL initially increased before decreasing, peaking at $20^{\circ}$. N under LL decreased as slope angle increased. N under ML was predominantly not affected by slope, and N under HL recorded an increase as the angle of slope increased.

Our results indicate that the development process of rill morphological parameters under different soil types are similar, recording rapid increases under a light rain intensity and a gentle slope, however the level of increment was small. Under a heavy rain intensity and a steep slope, rill morphological parameters initially rapidly increased before the rate of increase declined; the level of increment of rapid increase was larger. In the early stage of rill development, the converging effect of rill development on runoff gradually increased, and converging runoff further promoted the rapid development of rills. With the continuous development of rills, the converging effect of rills on runoff gradually weakened, decreasing rill development. Our results are consistent to those of $\mathrm{Wu}$ et al. (2018) who examined feedback coupling effects between rill morphology and rill erosion. Our results also indicated that morphological characteristics of rill development in different soil types differ. The development of rills under SL was mainly due to an increase of Wa and J; rill development under HL was mainly due to an increase of CDL, J and N. The index parameters of LL and ML rill development were between SL and HL. At the end of the rainfall experiment, Ha had no obvious order relationship, however the speed of increase differed during the rainfall events. The main reason for this phenomenon is that rill widening is mainly caused by collapse of the rill wall and merging of adjacent rills under gravity (Mancilla et al., 2005; Shen et al., 2015). An increase in rill length is mainly caused by an increase in the number of rills and rill head advance under traceable erosion (Schneider et al., 2013; Wu et al 2018). An increase in rill depth is mainly caused by further retrogressive erosion of rills due to undercutting, 
caused by runoff shear dispersion and the reemergence of rill head undercutting in rills (Gomez et al., 2003; Zhang et al., 2017; Zhao et al., 2018). A higher level of soil cohesion, due to higher levels of clay and organic matter content, make it easier for soil to form a mass structure, especially as clay content in a soil can significantly enhance the anti-dispersion ability of the wet soil layer. Soil structure stability is the important factor here. Therefore, Wa of HL slopes was smaller, being less than $5 \mathrm{~cm}$. Under the condition that rills easily occur, stripping erosion due to runoff further intensifies the headward erosion of rills. SL soil only had a clay content of $12.1 \%$ and the lowest organic matter content of the four soils, resulting in this soil to have poor structural stability. In addition, the sand content of SL peaked at $68.5 \%$, resulting in the soil to be loose and porous. Once a rill formed in SL, the rill wall and gully head readily collapsed under runoff effects, thus aggravating slope erosion. Due to differences in rill development mode between SL and HL, Ha in SL was mainly developed by further retrogressive erosion of the rill head after rill collapse, characterized by a phased increase; Ha in HL was mainly developed by rill bottom cutting whilst the rill length increased, characterized by a gradual increase. At the same time, due to differences in rill development mode between SL and HL, the negative effect of SL rill development on runoff convergence slowly weakened, and the negative effect of HL rill development on runoff convergence weakened faster. Therefore, after rill formation, SL erosion is more severe and lasts longer.

Results from this analysis indicate that rainfall intensity has a positive effect on rill morphological parameters for all soils, and sensitivity of rill parameters to rainfall intensity was: $\mathrm{N}>\mathrm{DS}>\mathrm{J}>\mathrm{Wa}>\mathrm{CDL}$ [?] Ha. The angle of slope had both positive and negative effects on SL, LL and ML rill morphological parameters, with only positive effects on HL. The sensitivity of rill parameters to slope response had the order of: Ha > Wa [?] $\mathrm{J}>\mathrm{DS}[?] \mathrm{N}>\mathrm{CDL}$.

\subsection{Correlation between influencing factors and relevant parameters of erosion processes}

In order to examine the influence of influencing factors on slope erosion, Pearson correlation analysis was used on influencing factors, runoff and sediment parameters, and rill shape parameters (Table 3 and Table 4). Results indicate that clay, silt and MWD were significantly positively correlated with the amount of erosion and rill erosion, and sand and OM was significantly negatively correlated with the amount of erosion and rill erosion (Table 3). The correlation of soil characteristic factors with rill morphological parameters indicated that clay and silt are significantly positive correlated with CDL, DS, J and N. Significant negative correlations were recorded between clay and Wa, and a significant negative correlation was recorded between silt and Wa, Ha; a significant positive correlation between sand and Wa, Ha was recorded, and a significant negative correlation was recorded between sand and CDL, DS, J and N. A significant positive correlation was found between OM and MWD and CDL, DS, J and N. finally, a significant negative correlation existed between OM, MWD and Wa, Ha. These findings correlate the rationality of our previous analysis.

As soil characteristics also affect slope roughness after erosion, they also affect flow velocity between interrills and rill, thereby having an important indirect impact on the development of erosion and rill morphology. As shown in Table 4, clay, silt and MWD were significantly positively correlated with Q and V, and significantly negatively correlated with T1 and VL. Sand was significantly positively correlated with T1 and VL and significantly negatively correlated with $\mathrm{Q}$ and $\mathrm{V}$. OM was positively correlated with $\mathrm{T} 1$ and $\mathrm{V}$, and negatively correlated with Q. Wa and Ha were negatively correlated with V, CDL, DS and J; N was negatively correlated with VL and positively correlated with Wa.

\subsection{A multi-type soil erosion prediction model based on rill development}

Correlation analysis shows that soil characteristic factors seriously affect slope erosion, thus the establishment of a quantitative index of soil characteristics in this study took erosion amount as the objective function. Soil characteristic factors with a significant correlation with erosion amount were selected to establish a regression relationship, thereby forming a comprehensive quantitative parameter $(\mathrm{C})$. By using multiple 
linear regression in SPSS, the silt factor was eliminated due to collinearity, and the equation was established as:

$\mathrm{C}=4.220$ clay +0.392 sand +49.986 MWD-10.55 OM R $\mathrm{R}^{2}=0.814$ (1)

This analysis indicates that the change of erosion amount has a synchronous effect with rill morphology evolution. In this study, we adopted the same method as that used by Zhang et al. (2019), constructing the rill morphology expression $(\mathrm{G})$ as:

$\mathrm{G}=6.271 \mathrm{CAL}+1.108 \mathrm{Wa}+2.100 \mathrm{DS}+0.862 \mathrm{~N} \mathrm{R}^{2}=0.926(2)$

Based on the constructed soil characteristic factor C and rill form G, combined with the main factors of rainfall, rainfall intensity and slope that affect soil erosion, the prediction model of slope erosion in the loess area was established as:

$\mathrm{R}^{2}=0.919(3)$

where, $\mathrm{D}$ is the erosion module of individual rainfall under a bare slope $\left(\mathrm{kg} \mathrm{m}^{-2}\right) ; P$ is rainfall $(\mathrm{mm}) ; I$ is rainfall intensity $(\mathrm{mm} / \mathrm{h})$; and $S$ is slope $(\mathrm{deg})$. The model was validated using 78 independent data sets (Fig. 10), and $\mathrm{R}^{2}$ between the measured value and the simulated value was 0.919 , indicating that the equation could suitably predict slope erosion.

\section{Conclusions}

In this study, erosion and rill morphology for four soils in the Loess Plateau, China, were compared under different artificial conditions. Results indicated that soil erosion differences among SL, LL and ML were mainly caused by different rill erosion processes. Soil erosion rates recorded varying degrees of increase with rill erosion under the four soil types: SL recorded a sharp increase, LL recorded a strong increase, and ML and HL recorded slight increases. HL was the most prone to the occurrence of rills; SL, LL and ML are prone to the occurrence of rills under heavy rain. The development of rills under SL was mainly characterized by an increase in Wa and N; the development of rills under HL were mainly characterized by an increase of CDL, $\mathrm{J}$ and N. Rill development indices for LL and ML were between those of SL and HL. The sensitivity of rill parameters to rainfall intensity was in the order of: $\mathrm{N}>\mathrm{DS}>\mathrm{J}>\mathrm{Wa}>\mathrm{CDL}$ [?] Ha, and sensitivity to slope was in the order of: $\mathrm{Ha}>$ Wa [?] J $>$ DS [?] N $>$ CDL. Soil properties may affect rill formation by changing the distribution of slope flow and the stability of soil particles being stripped and scoured. At the same time, soil properties may also affect the relationship between rill morphology, rainfall intensity and slope by changing soil structure stability; rill morphology enhances the difference of different types of soil erosion by changing the distribution of water flow between and within rills. In addition, an empirical relationship based on soil characteristic factors, rill shape parameters and soil erosion were established to reflect the influence of soil characteristics and rill shape on soil erosion. These results improve our understanding of the effects of soil properties on soil erosion and rill morphology in the Loess Plateau.

\section{References}

Assouline, S., Govers, G., Nearing, M.A. (2017). Erosion and Lateral Surface Processes. Vadose Zone Journal , 16(12). doi:10.2136/vzj2017.11.0194

Bagarello, V., Ferro, V., \& Giordano, G. (2010). Testing alternative erosivity indices to predict event soil loss from bare plots in southern Italy. Hydrological Processes , 24(6), 789-797. doi.org/10.1002/hyp.7538

Berger, C., Schulze, M., Rieke-Zapp D. (2010). Rill development and soil erosion: a laboratory study of slope and rainfall intensity. Earth Surface Processes and Landforms , 2010, 35(12):1456-1467. doi:10.1002/esp.1989 
Bonilla, Carlos A., Johnson, Odette I. (2012). Soil erodibility mapping and its correlation with soil properties in Central Chile.Geoderma , 189-190, 116-123. doi:10.1016/j.geoderma.2012.05.005

Castro Filho,C., Lourenco, A., Guimaraes, M.F., Fonseca, I.C.B. (2002). Aggregate stability under different soil management systems in a red latosol in the state of Parana, Brazil. Soil Tillage Research , 65, 45-51. doi:10.1016/s0167-1987(01)00275-6

Dong, Y.Q., Zhuang, X.H., Lei, T.W., Yin, Z., Ma, Y.Y. (2014). A method for measuring erosive flow velocity with simulated rill.Geoderma , 232-234, 556-562. doi:10.1016/j.geoderma.2014.06.014

Fang, H.Y., Sun, L.Y., Tang, Z.H. (2015). Effects of rainfall and slope on runoff, soil erosion and rill development: an experimental study using two loess soils. Hydrological Processes , 29(11), 26492658. doi:10.1002/hyp.10392

Foster, G.R., Flanagan, D.C., Nearing, M. A., Lane, L.J., Risse, L.M., \& Finkner, S.C. (1995). Hillslope erosion component. WEPP: USDA-Water Erosion Prediction Project, 11.1-11.12.

Gomez, J. A., Darboux, F., Nearing, M. A. (2003). Development and evolution of rill networks under simulated rainfall. Water Resources Research , 39(6), 1148. doi.org/10.1029/2002WR001437

Gordon, L.M., Bennett, S.J., \& Wells, R.R. (2012). Response of a soil-mantled experimental landscape to exogenic forcing. Water Resources Research , 48. doi.org/10.1029/2012WR012283

Govers, G., Gimenez, R., Van Oost, K. (2007). Rill erosion: Exploring the relationship between experiments, modelling and field obser-vations.Earth-Science Reviews , 84(34), 87-102. doi.org/10.1016/j.earscirev.2007.06.001

Guo, W. Z., Bai, Y., Cui, Z. Q., Wang, W. L., Li, J. M., Su, Z. G. (2020). The impact of concentrated flow and slope on unpaved loess-road erosion on the Chinese Loess Plateau. Land Degradation 85 Development . doi:10.1002/ldr.3774

Guo, W.Z., Xu, X.Z., Zhu, T.X., Zhang, H.W., Wang, W.L., Liu, Y.K., Zhu, M.D. (2019). Changes in particle size distribution of suspended sediment affected by gravity erosion: a field study on steep loess slopes. Journal of Soils and Sediments , 20(3):1730-1741. doi:10.1007/s11368-019-02496-z

He, J.J., Li, X.J., Jia, L.J., Gong, H.L., Cai, Q.G. (2014). Experimental Study of Rill Evolution Processes and Relationships between Runoff and Erosion on Clay Loam and Loess. Soil Science Society of America Journal , 78(5). doi:10.2136/sssaj2014.02.0063

He, J.J., Sun, L.Y., Gong, H.L., Cai, Q.G. (2017). Laboratory Studies on the Influence of Rainfall Pattern on Rill Erosion and Its Runoff and Sediment Characteristics. Land Degradation 85 Development . doi:10.1002/ldr.2691

Jerzy. L., Czyż, E.A., Dexter. A.R., Siczek, A. (2018). Effects of soil deformation on clay dispersion in loess soil. Soil and Tillage Research , 184:203-206. doi:10.1016/j.still.2018.08.005

Knapen, A., Poesen, J, Govers, G., Gyssels, G., Nachtergaele, J. (2017). Resistance of soils to concentrated flow erosion: A review.Earth-Science Reviews , 80(1-2), 75-109. doi:10.1016/j.earscirev.2006.08.001

Komatsu H., Shinohara Y., Kume T. (2011). Changes in peak flow with decreased forestry practices: Analysis using watershed runoff data.Journal of Environmental Management , 2011, 92(6):15281536. doi:10.1016/j.jenvman.2011.01.010

Langhans, C., Govers, G., Diels, J., Stone, J. J., Nearing, M. A. (2014). Modeling scale-dependent runoff generation in a small semi-arid watershed accounting for rainfall intensity and water depth. Advances in Water Resources , 69, 6 5-78. doi.org/10.1016/j. dvwatres.2014.03.005

Li, Y.S., Han, S.F., Wang, Z.H. (1985). Soil water properties and its zonation in the Loess Plateau. Menoir NSWC Acad. Sin. 2, 1-17 (in Chinese). 
Madenoglu, S., Atalay, F., Erpul, G. (2020). Uncertainty assessment of soil erodibility by direct sequential Gaussian simulation (DSIM) in semiarid land uses. Soil and Tillage Research , 204, 104731. doi:10.1016/j.still.2020.104731

Mancilla, G.A., Chen, S., McCool, D.K.(2005) Rill density prediction and flow velocity distributions on agricultural areas in the Pacific Northwest. Soil and Tillage Research , 84(1), 54-66. doi.org/10.1016/j.still.2004.10.002

Nelson, D.W., Sommer, L.E. (1982). Total carbon, organic carbon, and organic matter. In: Page, A.L. (Ed.), Methods of Soil Analysis: Chemical and Microbiological PropertiesASA Monograph. Am. Soc. Agron., Madison , 539-579. doi:10.2136/sssabookser5.3.c34

Neyshabouri, M.R., Ahmadi, A., Rouhipour, H., Asadi, H., Irannajad, M. (2011). Soil texture fractions and fractal dimension of particle size distribution as predictors of interrill erodibility. Turk. J. Agric. For. 35, 95-102. doi:10.3906/tar-0911-30

Owoputi, L.O., Stolte, W.J. (1995). Soil detachment in the physically based soil erosion process: a review. Trans. ASAE 38, 1099-11. doi:10.13031/2013.27927

Oz, I., Arav, R., Filin, S., Assouline, S., Furman, A. (2017). High-resolution measurement of topographic changes in agricultural soils. Vadose Zone Journal , 16(12). doi.org/10.2136/vzj2017.07.0138

Rienzi, E.A., Fox, J.F., Grove, J.H., Matocha, C.J. (2013). Interrill erosion in soils with different land uses: The kinetic energy wetting effect on temporal particle size distribution. Catena107:130-138. doi:10.1016/j.catena.2013.02.007

Ries, J.B., Marzen, M., Iserloh, T., Fister, W. (2014). Soil erosion in Mediterranean landscapes - Experimental investigation on crusted surfaces by means of the Portable Wind and Rainfall Simulator.Journal of Arid Environments , 100-101, 42-51. doi:10.1016/j.jaridenv.2013.10.006

Robichaud, P.R., Wagenbrenner, J.W., Elliot, W.J. (2020). Rill erosion in natural and disturbed forests: 1. Measurements. Water Resources Research , 46, W10506. doi.org/10.1029/2009WR008314

Schneider, A., Gerke, H.H., Maurer, T., Nenov, R. (2013). Initial hydro-geomorphic development and rill network evolution in an artificial catchment. Earth Surface Processes and Landforms , 38(13), 14961512. doi:10.1002/esp.3384

Shen, H., Zheng, F.L., Wen, L.L., Han, Y., Hu, W. (2016). Impacts of rainfall intensity and slope gradient on rill erosion processes at loessial hillslope. Soil and Tillage Research , 155, 429436. doi:10.1016/j.still.2015.09.011

Shen, H., Zheng, F.L., Wen, L.L., Lu, J., Jiang, Y.L. (2015). An experimental study of rill erosion and morphology. Geomorphology, 231, 193-201. doi:10.1016/j.geomorph.2014.11.029

Sun, L.Y., Zhou, J.L., Cai, Q.G. (2020). Impacts of soil properties on flow velocity under rainfall events: Evidence from soils across the Loess Plateau. catena , 194, 104704. doi:10.1016/j.catena.2020.104704

Vaezi, A.R., Ahmadi, M., Cerdà, A. (2018). Contribution of raindrop impact to the change of soil physical properties and water erosion under semi-arid rainfalls. Science of The Total Environment, 583, 382392. doi:10.1016/j.scitotenv.2017.01.078

Vaezi, A.R., Zarrinabadi, E., Auerswald, K. (2017). Interaction of land use, slope gradient and rain sequence on runoff and soil loss from weakly aggregated semi-arid soils.Soil and Tillage Research , 172, 2231. doi:10.1016/j.still.2017.05.001

Vereecken, H., Schnepf, A., Hopmans, J.W., Javaux, M., Or, D., Roose, T., Vanderborght, J. (2016). Modeling soil processes: Review, key challenges, and new perspectives. Vadose Zone Journal , 15(5). doi.org/10.2136/vzj2015.09.0131 
Wu, S., Chen, L., Wang, N., Yu, M., Assouline, S. (2018). Modeling rainfall-runoff and soil erosion processes on hillslopes with complex rill network planform. Water Resources Research , 54, 10,117-10,133. doi.org/10.1029/2018WR023837

Wu, S.B., Chen, L. (2020). Modeling Soil Erosion with Evolving Rills on Hillslopes. Water Resources Research , 56(10). doi:10.1029/2020WR027768

Wu, X.L., Wei, Y.J., Wang, J.G., Wang, D., She, L., Wang, J., Cai, C.F. (2017). Effects of soil physicochemical properties on aggregate stability along a weathering gradient. Catena , 156, 205215. doi:10.1016/j.catena.2017.04.017

Xu, X.Z., Liu, Z.Y., Xiao, P.Q., Guo, W.Z., Zhang, H.W., Zhao, C., Yan, Q. (2015). Gravity erosion on the steep loess slope: Behavior, trigger and sensitivity. catena, 135, 231-239. doi:10.1016/j.catena.2015.08.005

Zhang, Q. W., Lei, T. W., Huang, X. J. (2016). Quantifying the sediment transport capacity in eroding rills using a REE tracing method.Land Degradation 83 Development . doi:10.1002/ldr.2535

Zhang, P., Yao, W., Tang, H., Wei, G., Wang, L. (2017). Laboratory investigations of rill dynamics on soils of the Loess Plateau of China.Geomorphology , 293:201-210. doi:10.1016/j.geomorph.2017.06.003

Zhang, P., Yao, W., Liu, G., Xiao, P. (2019). Experimental study on soil erosion prediction model of loess slope based on rill morphology.Catena , 173, 424-432. doi:10.1016/j.catena.2018.10.034

Zhao, L., Hou, R., \& Wu, F. (2018). Effect of tillage on soil erosion before and after rill development. Land Degradation \& Development , 29(8), 2506-2513. doi:10.1002/ldr.2996

Table 1. Soil properties from the study site

\begin{tabular}{|c|c|c|c|c|c|c|}
\hline Sampling sites & $\begin{array}{l}\text { Texture } \\
\text { category }\end{array}$ & $\begin{array}{l}\text { Mechanical } \\
\text { composition } \\
(\%)\end{array}$ & $\begin{array}{l}\text { Mechanical } \\
\text { composition } \\
(\%)\end{array}$ & $\begin{array}{l}\text { Mechanical } \\
\text { composition } \\
(\%)\end{array}$ & MWD $(\mathrm{mm})$ & $\mathrm{OM}\left(\mathrm{g} \cdot \mathrm{Kg}^{-1}\right)$ \\
\hline & & Clay & silt & Sand & & \\
\hline Suide & $\begin{array}{l}\text { Sandy loam } \\
\text { (SL) }\end{array}$ & $\begin{array}{l}<0.002 \mathrm{~mm} \\
12.1\end{array}$ & $\begin{array}{l}0.002-0.02 \mathrm{~mm} \\
19.4\end{array}$ & $\begin{array}{l}0.02-2 \mathrm{~mm} \\
68.5\end{array}$ & 6.6 & 5.9 \\
\hline Ansai & $\begin{array}{l}\text { Light loam } \\
\text { (LL) }\end{array}$ & 15.7 & 26.8 & 57.5 & 20.7 & 7.4 \\
\hline Changwu & $\begin{array}{l}\text { Medium } \\
\text { loam (ML) }\end{array}$ & 21.2 & 38.0 & 40.8 & 51.8 & 12.3 \\
\hline Yangling & $\begin{array}{l}\text { Heavy loam } \\
\text { (HL) }\end{array}$ & 26.3 & 38.1 & 35.6 & 76.4 & 18.3 \\
\hline
\end{tabular}

MWD: the mean weight diameter of aggregates after wet sieving; OM: Organic matter;

Table 2. Runoff characteristics before rill development

\begin{tabular}{lllllll}
\hline $\begin{array}{l}\text { Rainfall } \\
\text { intensity } \\
(\mathrm{mm} / \mathrm{h})\end{array}$ & Slope $\left(^{\circ}\right)$ & Soil & $\mathrm{T} 1(\mathrm{~min})$ & $\mathrm{T} 2(\mathrm{~min})$ & $\begin{array}{l}\mathrm{RRF}\left(\mathrm{ml} \mathrm{m}^{-2}\right. \\
\left.\mathrm{min}^{-1}\right)\end{array}$ & $\mathrm{VRF}(\mathrm{m} / \mathrm{s})$ \\
\hline 90 & 10 & SL & 5.9 & - & 781.50 & 0.13 \\
& & LL & 2.5 & - & 1282.89 & 0.23 \\
& & ML & 2.6 & - & 1241.40 & 0.26 \\
& & HL & 1.8 & 27.0 & 1652.26 & 0.23 \\
& 15 & SL & 7.5 & 27.1 & 669.33 & 0.13
\end{tabular}




\begin{tabular}{|c|c|c|c|c|c|c|}
\hline $\begin{array}{l}\text { Rainfall } \\
\text { intensity } \\
(\mathrm{mm} / \mathrm{h})\end{array}$ & Slope $\left(^{\circ}\right)$ & Soil & $\mathrm{T} 1$ (min) & $\mathrm{T} 2(\min )$ & $\begin{array}{l}\operatorname{RRF}\left(\mathrm{ml} \mathrm{m}^{-2}\right. \\
\left.\mathrm{min}^{-1}\right)\end{array}$ & $\operatorname{VRF}(\mathrm{m} / \mathrm{s})$ \\
\hline & & LL & 3.5 & - & 1495.33 & 0.29 \\
\hline & & ML & 3.1 & - & 1288.20 & 0.23 \\
\hline & & $\mathrm{HL}$ & 1.9 & 24.0 & 1519.38 & 0.21 \\
\hline & 20 & SL & 6.5 & - & 675.17 & 0.17 \\
\hline & & LL & 3.3 & 31.3 & 1487.33 & 0.30 \\
\hline & & ML & 2.1 & - & 937.73 & 0.19 \\
\hline & & HL & 1.3 & 16.8 & 1492.00 & 0.23 \\
\hline & 25 & SL & 7.8 & - & 513.72 & 0.32 \\
\hline & & LL & 3.2 & - & 1024.41 & 0.32 \\
\hline & & ML & 2.7 & 36.7 & 1138.29 & 0.18 \\
\hline & & HL & 1.3 & 9.8 & 1465.33 & 0.29 \\
\hline \multirow[t]{16}{*}{120} & 10 & SL & 3.8 & 18.1 & 1430.30 & 0.12 \\
\hline & & LL & 1.8 & 12.3 & 1148.57 & 0.22 \\
\hline & & ML & 2.2 & - & 2053.18 & 0.26 \\
\hline & & HL & 1.1 & 22.0 & 2073.00 & 0.22 \\
\hline & 15 & SL & 4.0 & 12.3 & 1624.14 & 0.14 \\
\hline & & LL & 1.1 & - & 1938.78 & 0.30 \\
\hline & & ML & 1.9 & 25.2 & 2003.33 & 0.26 \\
\hline & & HL & 1.0 & 12.4 & 2318.95 & 0.22 \\
\hline & 20 & SL & 4.1 & 20.4 & 901.05 & 0.11 \\
\hline & & LL & 1.6 & 30.4 & 1552.69 & 0.27 \\
\hline & & ML & 1.4 & 43.3 & 1861.95 & 0.28 \\
\hline & & HL & 1.4 & 10.0 & 2035.56 & 0.27 \\
\hline & 25 & SL & 4.8 & 22.4 & 494.22 & 0.13 \\
\hline & & LL & 7.5 & 10.7 & 1165.36 & 0.16 \\
\hline & & ML & 1.5 & 35.2 & 1844.12 & 0.28 \\
\hline & & HL & 1.8 & 18.4 & 1717.50 & 0.18 \\
\hline
\end{tabular}

T1: Time to runoff initiation; T2: Time to rill initiation; RRF: Runoff rate before rill appearance; VRF: Runoff velocity before rill appearance.

Table 3. Correlation between influencing factors and erosion parameters

\begin{tabular}{lllllllll}
\hline & Clay & silt & sand & MWD & OM & R & P & S \\
\hline T1 & $-0.69^{* *}$ & $-0.72^{* *}$ & $0.72^{* *}$ & $-0.69^{* *}$ & $0.68^{* *}$ & $-0.44^{* *}$ & -0.13 & 0.17 \\
$\mathrm{Q}$ & $0.41^{* *}$ & $0.43^{* *}$ & $-0.43^{* *}$ & $0.41^{* *}$ & $-0.40^{* *}$ & -0.15 & $0.75^{* *}$ & $-0.25^{*}$ \\
$\mathrm{D}$ & $0.43^{* *}$ & $0.24^{*}$ & $-0.33^{* *}$ & $0.38^{* *}$ & $-0.39^{* *}$ & $0.41^{* *}$ & $0.28^{* *}$ & $0.48^{* *}$ \\
$\mathrm{DR}$ & $0.47^{* *}$ & $0.33^{* *}$ & $-0.39^{* *}$ & $0.42^{* *}$ & $-0.32^{* *}$ & $0.31^{* *}$ & $0.39^{* *}$ & $0.45^{* *}$ \\
$\mathrm{~V}$ & $0.23^{*}$ & $0.39^{* *}$ & $-0.33^{* *}$ & $0.25^{*}$ & $0.46^{* *}$ & -0.01 & 0.09 & $0.30^{* *}$ \\
$\mathrm{VL}$ & $-0.43^{* *}$ & $-0.28^{*}$ & $0.35^{* *}$ & $-0.39^{* *}$ & -0.16 & $0.24^{*}$ & 0.01 & -0.07 \\
$\mathrm{CDL}$ & $0.58^{* *}$ & $0.43^{* *}$ & $-0.50^{* *}$ & $0.54^{* *}$ & $0.29^{* *}$ & -0.13 & $0.53^{* *}$ & $0.31^{* *}$ \\
$\mathrm{Wa}$ & $-0.72^{* *}$ & $-0.68^{* *}$ & $0.70^{* *}$ & $-0.69^{* *}$ & $-0.59^{* *}$ & $0.36^{* *}$ & $0.33^{* *}$ & -0.06 \\
$\mathrm{Ha}$ & -0.20 & $-0.30^{* *}$ & $0.26^{*}$ & -0.21 & $-0.34^{* *}$ & -0.04 & $0.40^{* *}$ & 0.10 \\
$\mathrm{DS}$ & $0.650^{* *}$ & $0.48^{* *}$ & $-0.56^{* *}$ & $0.60^{* *}$ & $0.32^{* *}$ & -0.12 & 0.20 & 0.21 \\
$\mathrm{~J}$ & $0.51^{* *}$ & $0.36^{* *}$ & $-0.43^{* *}$ & $0.48^{* *}$ & $0.23^{*}$ & 0.05 & 0.17 & $0.25^{*}$ \\
$\mathrm{~N}$ & $0.53^{* *}$ & $0.37^{* *}$ & $-0.44^{* *}$ & $0.48^{* *}$ & $0.24^{*}$ & 0.09 & 0.11 & $0.24^{*}$ \\
\hline
\end{tabular}


MWD: the mean weight diameter of aggregates after wet sieving; OM: Organic matter; I: Rainfall intensity, $\mathrm{mm} / \mathrm{h}$; P: rainfall, mm; S: slope gradient, ${ }^{\circ}$; T1 Time to runoff initiation, min; Q: Flow discharge, L; D: Sediment yield, Kg; DR: Rill sediment yield, Kg; V: Interrill flow, m/s; VL: Rill flow, m/s. CAL: Rill cumulative length, m; LM: Maximum length of rill, m; Wa: Rill mean width, cm; Ha: Rill mean depth, cm; DS: Rill density, $\mathrm{m} / \mathrm{m}^{2} ; \mathrm{J}$ : Merge nodes; N: Number of rills. ${ }^{* *}$ indicates a significant correlation at $\mathrm{p}<0.01$; $*$ indicates a significant correlation at $\mathrm{p}<0.05$.

Table 4. Correlation between runoff, sediment parameters and rill morphological parameters

\begin{tabular}{|c|c|c|c|c|c|c|c|c|c|c|c|}
\hline & $\mathrm{Q}$ & $\mathrm{D}$ & DR & $\mathrm{V}$ & VL & $\mathrm{CDL}$ & $\mathrm{Wa}$ & $\mathrm{Ha}$ & $\mathrm{DS}$ & $\mathrm{J}$ & $\mathrm{N}$ \\
\hline $\mathrm{Q}$ & 1 & & & & & & & & & & \\
\hline D & $0.45^{* *}$ & 1 & & & & & & & & & \\
\hline DR & 0.14 & $0.76^{* *}$ & 1 & & & & & & & & \\
\hline V & $0.32^{* *}$ & $0.37^{* *}$ & 0.20 & 1 & & & & & & & \\
\hline VL & -0.05 & $0.29^{* *}$ & $0.40^{* *}$ & $0.28^{*}$ & 1 & & & & & & \\
\hline CDL & $0.34^{* *}$ & $0.79^{* *}$ & $0.88^{* *}$ & 0.15 & $-0.31^{* *}$ & 1 & & & & & \\
\hline Wa & -0.15 & $0.31^{* *}$ & $-0.45^{*}$ & $-0.29^{* *}$ & $0.43^{* *}$ & $-0.38^{* *}$ & 1 & & & & \\
\hline $\mathrm{Ha}$ & 0.06 & $0.35^{* *}$ & -0.03 & $-0.24^{*}$ & 0.11 & $0.32^{* *}$ & $0.54^{* *}$ & 1 & & & \\
\hline DS & $0.42^{* *}$ & $0.82^{* *}$ & $0.86^{* *}$ & 0.12 & $-0.40^{* *}$ & $0.94^{* *}$ & $-0.42^{* *}$ & $0.26^{*}$ & 1 & & \\
\hline $\mathrm{J}$ & $0.30^{* *}$ & $0.82^{* *}$ & $0.84^{* *}$ & 0.01 & $-0.35^{* *}$ & $0.92^{* *}$ & $-0.30^{* *}$ & $0.30^{* *}$ & $0.88^{* *}$ & 1 & \\
\hline $\mathrm{N}$ & $0.24^{*}$ & $0.80^{* *}$ & $0.86^{* *}$ & 0.07 & $-0.34^{* *}$ & $0.91^{* *}$ & $-0.35^{* *}$ & $0.27^{*}$ & $0.89^{* *}$ & $0.96^{* *}$ & 1 \\
\hline
\end{tabular}

Q: Flow discharge, L; D: Sediment yield, Kg; DR: Rill sediment yield, Kg; V: Interrill flow, m/s; VL: Rill flow, m/s. CAL: Rill cumulative length, m; Wa: Rill mean width, cm; Ha: Rill mean depth, cm; DS: Rill density, $\mathrm{m} / \mathrm{m}^{2} ; \mathrm{J}$ : Merge nodes; N: Number of rills. ** indicates a significant correlation at $\mathrm{p}<0.01$; indicates a significant correlation at $\mathrm{p}<0.05$.

\section{Hosted file}

Piture .pdf available at https://authorea.com/users/350511/articles/505421-rill-morphologicalchange-characteristics-and-influencing-factors-on-different-soil-types-in-the-loessplateau-china 